\title{
Intraoperative Ultrasound and Contrast-Enhanced Ultrasound (CEUS) Features in a Case of Intradural Extramedullary Dorsal Schwannoma Mimicking an Intramedullary Lesion
}

\section{Merkmale des intraoperativen und kontrastver- stärkten Ultraschalls (CEUS) bei einem intraduralen extramedullären dorsalen Schwannom, das eine intramedulläre Läsion nachahmt}

\section{Introduction \\ $\nabla$}

Primary spinal tumors are relatively rare lesions, representing $4-8 \%$ of all central nervous system tumors (Duong LM et al. Cancer 2012; 118: 4220 - 4227). Magnetic resonance imaging (MRI) represents the gold standard for the diagnosis and assessment of intradural tumors. Nevertheless, sometimes MRI may not accurately differentiate between intramedullary and extramedullary tumors. The role of intraoperative ultrasound (ioUS) on the other hand is not yet well-defined and standardized for this surgical field.

We report a case of a dorsal schwannoma in which preoperative MRI showed findings compatible with an intramedullary lesion with an exophitic component. However, ioUS with the adjunct of contrast-enhanced ultrasound (CEUS) helped to reveal the lesion to be completely extramedullary. To the best of our knowledge, this is the first reported case of use of CEUS during spinal tumor surgery.

\section{Case description \\ $\nabla$}

A 33-year-old female patient with a twomonth history of slowly progressive hypostenia of the lower extremities and dysesthesia of the left leg was admitted at our institution. An MRI scan showed the presence of an intradural dorsal lesion. No posterior scalloping of the vertebral body and widening of the neural foramina were recorded. MRI depicted widening of the spinal cord at the D3-D11 level. Focal enhancement of the tumor nidus at the D8-D9 level was seen. Associated pluri-sepimental enlargement of the ependymal canal or tumor cysts were also observed above and below the solid portion of the tumor at D3-D7 and D10-D11 levels, respectively.
The neuro-radiological diagnosis was intramedullary tumor ( $\bullet$ Fig. 1 ). The patient underwent surgery in the prone position via a posterior approach (D7-D9 laminectomy) and neurophysiological monitoring. After dural exposure, the surgical field was examined with transdural, direct B-mode and CEUS ultrasound, as we previously reported (Prada et al. Neurosurgery 2014; 74: 542 - 552). The standard B-mode imaging examination showed an ovular, hyperechoic lesion with cranial cystic areas and an ill-defined border caudally ( $\bullet$ Fig. 2). The spinal cord was not clearly visible and it was not possible to distinguish the edematous spinal cord from an infiltrative lesion. CEUS was performed, showing a slow and homogeneous enhancement of the lesion as compared to the spinal parenchyma, with a slow transit time and late wash-out. The peri-lesional cysts did not show contrast enhancement, nor did the edematous spinal cord surrounding the lesion ( $\bullet$ Fig. 3 ).

Intraoperatively, we found no differences between the tumoral and medullary surface. Guided by the information that the lesion was intramedullary, dissection was performed along the midline, revealing a fine capsule, which was sent for intraoperative histological examination. The results indicated a schwannoma.

The lesion was debulked. We then found a pseudocleavage plane with the spinal cord. The lesion showed a cranial portion embedded and firmly attached to the spinal cord and a posterior central exophitic component.

The tumor originated from a posterior rootlet, and was completely resected with a microneurosurgical technique, as confirmed by IoUS control at the end of the procedure ( $\bullet$ Fig. 3 ).

The patient had an uneventful postoperative course and was sent to undergo phys- ical rehabilitation. At the three-month follow-up, the patient showed full recovery of her motor symptoms while still presenting mild proprioceptive deficit.

\section{Discussion \\ $\nabla$}

MRI represents the gold standard for the diagnosis of intradural tumors. However, as shown in this case, MRI findings can sometimes be misinterpreted. Some minor details were not considered in the correct diagnosis. In sagittal T2 and T1-weighted images post-gadolinium, a small portion of the tumor showed contrast enhancement and growths in the extramedullary space. The medullary cord appeared invaded but also compressed and displaced in the spinal canal. The cysts above and below the solid portion of the lesion were considered as part of the tumor and not as tumor-associated syringomielia. However, the differentiation of tumor-associated cysts and tumor-associated syringomielia is difficult, even with the use of contrast enhancement. Another misleading finding was the presence of a satellite cyst at the preoperative MRI, often present in intramedullary lesions such as ependymomas. Furthermore, the altered spinal cord signal cranial and caudal to the lesion due to the edematous tissue indicated an intramedullary tumor. The surgical technique differs between intramedullary and extramedullary lesions, and the differentiation is of critical importance not only for surgical strategy but also when explaining the potential risks and benefits of surgery to the patient.

IoUS might also represent a useful tool for spinal tumor surgery, as we previously reported in a study about the ioUS characteristics of different spinal lesions and its role in surgical planning and during spinal tumor resection (Prada $\mathrm{F}$ et al. J Ultrasound 2014; 17: 195-202). The main role of ioUS examination is to assist in the exact localization of intradural tumors. Standard B-mode examination usually is sufficient to depict the lesion prior to dural opening. A normal spinal cord in most cases appears hypoechoic, whereas in our case it appeared highly hyperechoic because of consistent edema, and it was therefore not possible to distinguish between the lesion and the compressed spinal cord.

As already established in brain tumor surgery, iCEUS is indeed a valuable tool to better highlight cerebral lesions (Prada F. 


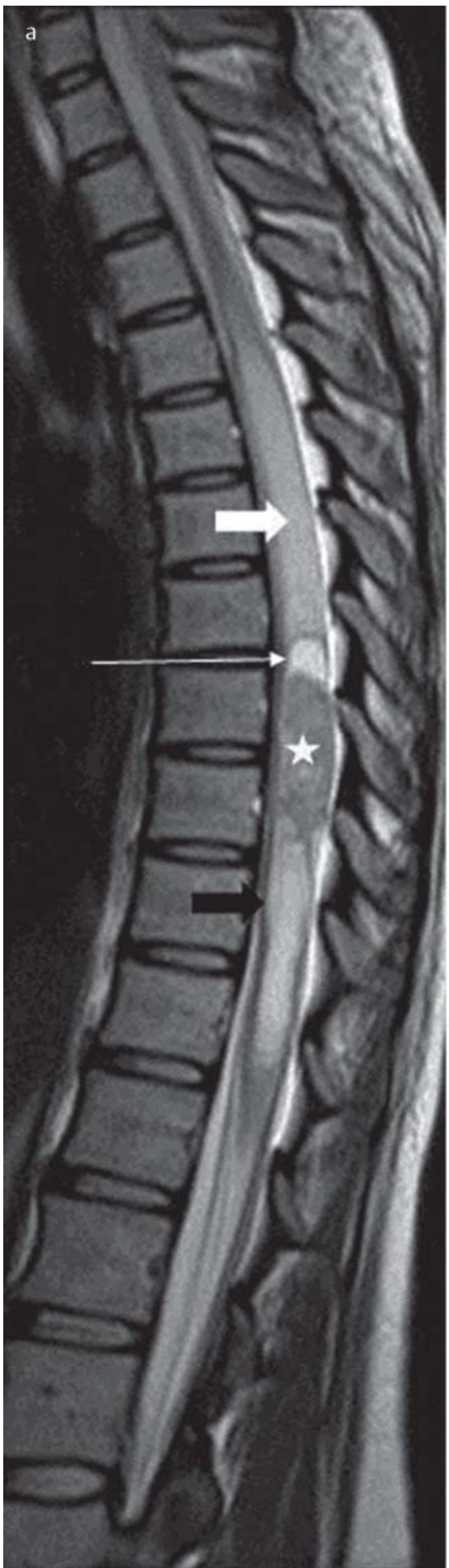

Fig. 1 Preoperative MRI. Sagittal T2- a and T1- b, axial T2- c-e and axial T1- $\mathbf{d}-\mathbf{f}$ weighted images. a, b show widening of the spinal cord at the dorsal level (D3-D11) and a tumor with a nodular enhancement component at the D8-D9 level (star). The spinal cord appears edematous above the lesion (thick arrow). Below it the spinal cord is less homogeneous and appears with thin superficial enhancement (black arrow) with less demarcated borders with the nodular portion. Associated plurisepimental enlargement of the ependymal canal or tumor cysts were also seen above the solid portion of the tumor (thin arrow). In c, d the tumor is growing in the extramedullary space and the spinal cord appears invaded, compressed and displaced into the spinal canal (thick arrows). Note in $\mathbf{e}, \mathbf{f}$ the enlargement of the ependymal canal or tumor cysts (thin arrows).
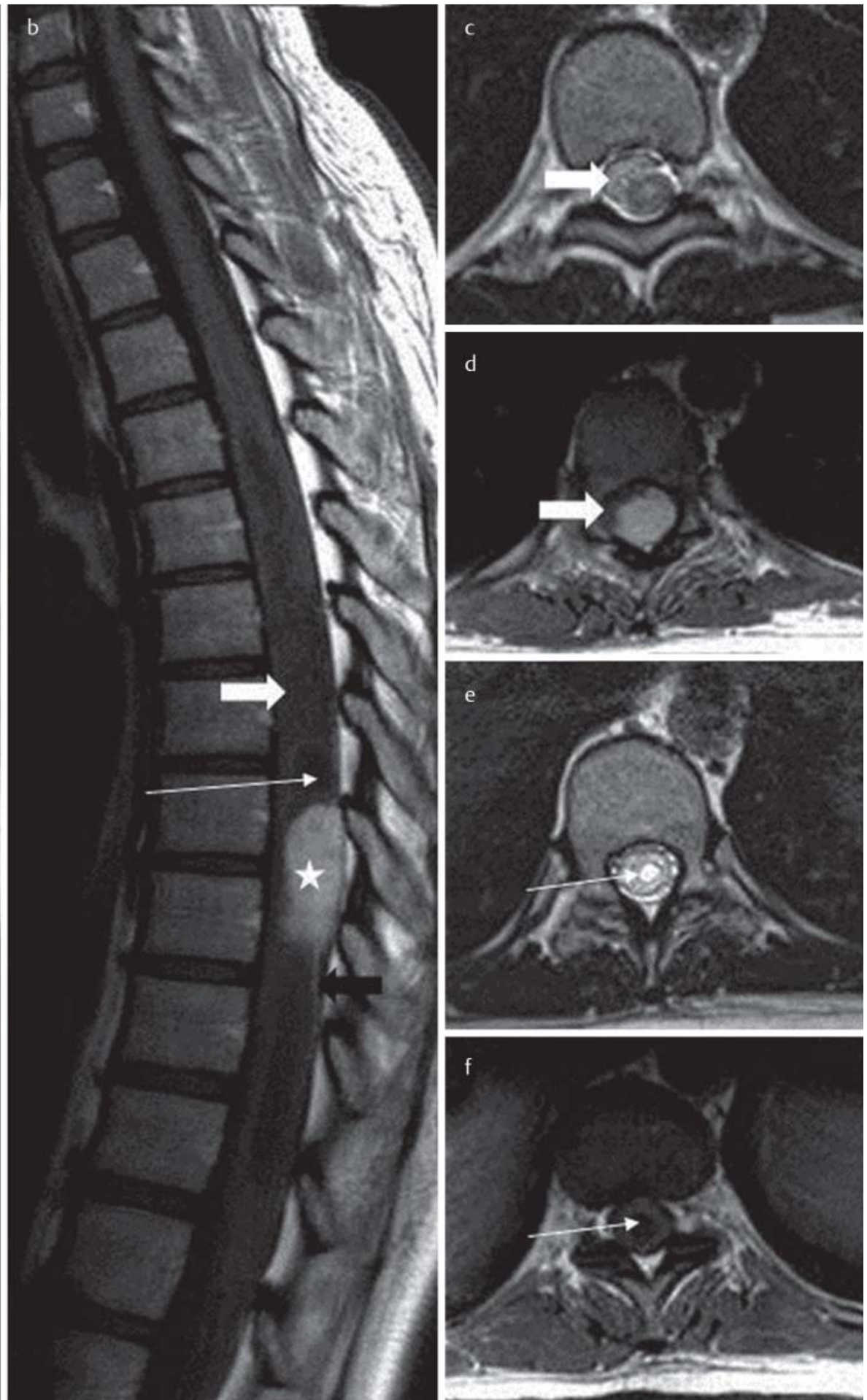

Abb. 1 Präoperative MRT. Sagittale T2- a, axiale T2- c-e und axiale T1- $\mathbf{d - f}$ gewichtete Bilder. a, b zeigen die Erweiterung des Rückenmarks in der dorsalen Ebene (D3-D11) und einem Tumor mit nodulare verstärkte Komponente in der D8-D9 Ebene (Stern). Das Rückenmark oberhalb der Läsion erscheint ödematös (dicker Pfeil), darunter ist das Rückenmark weniger homogen und erscheint mit dünner oberflächlicher Anreicherung (schwarzer Pfeil) mit weniger abgegrenzten Rändern im nodularen Teil. Ebenfalls ist eine damit assoziierte plurisepimentale Vergrößerung des Rückenmarkskanals oder der Tumorzyste im soliden Teil des Tumors (dünner Pfeil) zu erkennen. Bei c, $\mathbf{d}$ wächst der Tumor in den Extramedullärraum und das Rückenmark erscheint in den Spinalkanal eingedrungen, komprimiert und verschoben zu sein (dicke Pfeile). Zu beachten ist die Vergrößerung des Rückenmarkskanals oder der Tumorzysten bei e, $\mathbf{f}$ (dünne Pfeile). 

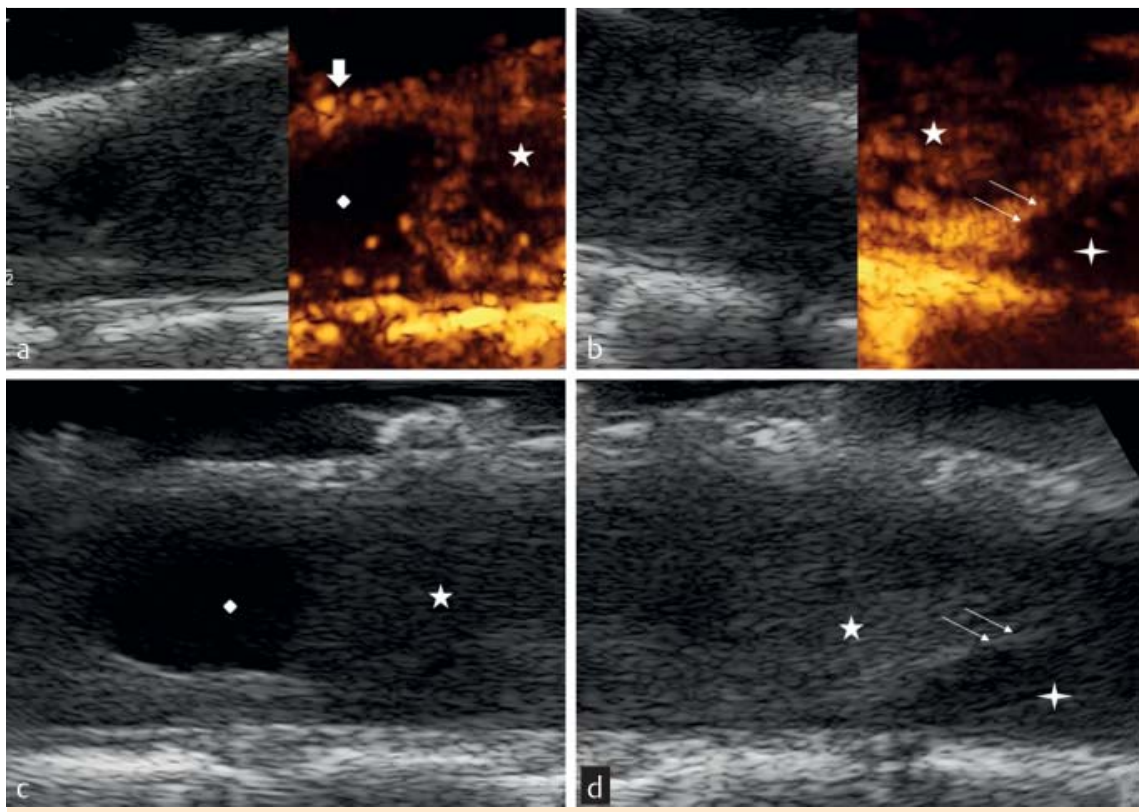

Fig. 2 Intraoperative US images of the tumor prior to resection. Captions a, b show intraoperative CEUS images of the cranial and caudal portion of the tumor, respectively. Captions $\mathbf{c}, \mathbf{d}$ depict corresponding grayscale B-mode images. The significant enhancement of the nodule (star) is visible, with a dotted pattern and multiple hypoperfusion areas $\mathbf{b}$, especially when compared to the standard Bmode in $\mathrm{c}$ and $\mathrm{d}$. The cranial peritumoral cyst (diamond) is visible as an hypoechoic area both in $\mathbf{a}$ and $\mathbf{c}$. The arrowhead in a shows a superficial congested venous plexus. The edematous spinal cord (cross in b, c) below the tumor did not show significant enhancement with CEUS, whereas the caudal portion of the lesion in $\mathbf{b}$ is highly enhanced (star). The thin arrows in $\mathbf{b}, \mathbf{d}$ show the interface between the tumor, highlighted with CEUS, and edematous spinal cord which is not enhanced, as visible in $\mathbf{b}$. On the contrary, as visible in $\mathbf{d}$, the difference between tumor and edematous spinal cord is not as clearly highlighted with standard B-mode. The border between tumor and spinal cord is slightly visible and it is represented by a thin hyperechoic line (double thin arrows).

Abb. 2 Intraoperative US-Bilder des Tumors vor Entfernung. Gezeigt sind die intraoperativen CEUSBilder der kranialen $\mathbf{a}$ und kaudalen $\mathbf{b}$ Anteile des Tumors. Unter $\mathbf{c}$ und $\mathbf{d}$ sind die korrespondierenden B-Bilder dargestellt. Sichtbar ist die signifikante Kontrastaufnahme des Knotens (Stern) mit gepunktetem Muster und multiplen ischämischen Abschnitten b, insbesondere im Vergleich zum Standard B-Bild bei c, d. Die kraniale peritumorale Zyste (Raute) ist als echoarmer Bereich sowohl bei a als auch bei $\mathbf{b}$ zu sehen. Die Pfeilspitze bei a zeigt den superfiziell gestauten Plexus venosus. Das ödematöse Rückenmark (Kreuz bei b, c) unterhalb des Tumors zeigt keine signifikante Kontrastaufnahme im CEUS, während der kaudale Teil der Läsion bei $\mathbf{b}$ deutlich verstärkt ist (Stern). Die dünnen Pfeile bei b, $\mathbf{d}$ zeigen die Grenzschicht zwischen dem im CEUS akzentuierten Tumor und dem ödematösen Rückenmark, das nicht verstärkt ist, wie in b zu sehen ist. Im Gegensatz dazu ist, wie in $\mathbf{d}$ zu sehen ist, der Unterschied zwischen dem Tumor und dem ödematösen Rückenmark im herkömmlichen B-Bild nicht so deutlich ausgeprägt. Die Grenze zwischen Tumor und Rückenmark ist kaum sichtbar und wird durch eine dünne echoreiche Linie präsentiert (doppelte dünne Pfeile).

et al. Neurosurgery 2014; 74: $542-552$ ) and obtain additional information regarding their vascularization and perfusion patterns (Prada F. et al. Biomed Res Int 2014; 2014: 484261 . DOI: 10.1155/2014/ 484261). Relying on our experience with iCEUS in brain tumor surgery, as described in our previous papers (Prada F. et al. Neurosurgery. 2014; 74: $542-552$; Prada F. et al. Biomed Res Int 2014; 2014: 484261. DOI: 10.1155/2014/484261. Epub 2014 Jun 12), we performed iCEUS during spinal tumor surgery such as in this case. As a contrast agent, we used sul- phur hexafluoride (Sonovue, Bracco, Italy). iCEUS was performed with a linear probe using low-power insonation. The consequent harmonic signals were transduced with contrast-specific modes. iCEUS made it possible to further highlight the lesion and differentiate it from the spinal cord, which did not show any contrast enhancement ( $\bullet$ Fig. 2). In particular, the anechoic polar cystic areas did not reveal contrast enhancement, giving useful information on the anatomic situation and facilitating the surgical strategy. In fact, even after dural opening, on direct

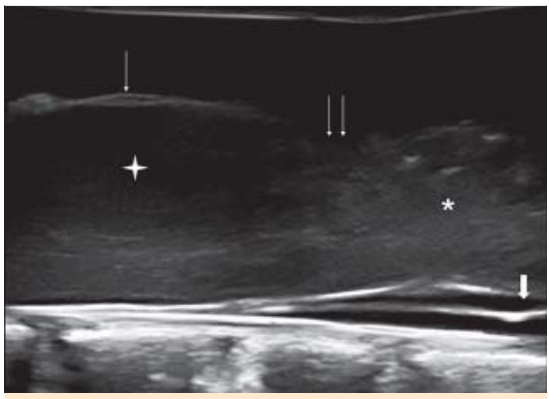

Fig. 3 loUS B-mode sagittal post-resection image that shows the surgical field after complete tumor resection. The double thin arrows show the area where the tumor was directly embedded within the spinal cord with disruption of the pia mater. The surface of the caudal spinal cord also shows some hyperechoic areas due to tissue manipulation and remains hyperechoic because of diffuse edema but appears nevertheless re-expanded (asterisks). Inferiorly the anterior perimedullary space has reappeared (bold arrow). The cranial spinal cord still remains hyperechoic (cross) with a more homogeneous texture and the superficial pia mater is still intact (single thin arrow).

Abb. 3 Das loUS sagittale B-Bild nach Resektion zeigt das chirurgische Feld nach kompletter Entfernung des Tumors. Die doppelten dünnen Pfeile zeigen auf den Bereich, wo der Tumor direkt ins Rückenmark eingebettet war mit Zerstörung der Pia mater. Die Oberfläche des kaudalen Rückenmarks zeigt auch einige echoreiche Abschnitte infolge der Gewebemanipulation und es bleibt echoreich aufgrund der diffusen Ödeme, dennoch wirkt es re-expandiert (Stern). Inferior ist der anteriore perimedulläre Raum wieder erschienen (dicker Pfeil). Die kraniale Rückenmark bleibt weiterhin echoreich (Kreuz) mit einer etwas homogeneren Textur und die oberflächliche Pia mater ist noch intakt (dünner Einzelpfeil).

microscopic observation, the spinal cord was anteriorly compressed and not visible, and the lesion still appeared very similar to the surrounding compressed neural tissue and was embedded into it in the polar areas. iCEUS limitations in this case were mainly due to technical aspects. In fact we were exploring a superficial lesion and the depth of the explored surgical field was highly reduced compared to brain surgery, giving us less defined imaging.

Nevertheless IoUS proved to be of high value in the surgical approach chosen, and iCEUS indeed offered further insight in highlighting the lesion and its boundaries and in describing its perfusion pattern.

I.G. Vetrano, F. Prada, A. Erbetta, F. DiMeco, Milan 